Article

\title{
Financial Deepening and Economic Growth Nexus in Nigeria: Supply-Leading or Demand-Following?
}

\author{
Tari Moses Karimo ${ }^{1, *}$ and Oliver Ejike Ogbonna ${ }^{2}$ \\ 1 Department of Economics, Niger Delta University, Wilberforce Island, P.O. Box 1464, Yenagoa 560001, \\ Bayelsa State, Nigeria \\ 2 Department of Economics, Faculty of the Social Sciences, University of Nigeria, Nsukka 410001, Enugu State, \\ Nigeria; ogbonna.oliver@yahoo.com \\ * Correspondence: trimoses@gmail.com
}

Academic Editor: Tapas Mishra

Received: 15 October 2016; Accepted: 7 January 2017; Published: 23 January 2017

\begin{abstract}
This paper examined the direction of causality between financial deepening and economic growth in Nigeria for the period 1970-2013. The study adopted the Toda-Yamamoto augmented Granger causality test and results showed that the growth-financial deepening nexus in Nigeria follows the supply-leading hypothesis. This means that it is financial deepening that leads to growth and not growth leading financial deepening. Among other things, the study recommended that policy efforts should be geared towards removing obstacles that undermine the growth of credit to the private sector, and must restore investors' confidence in the stock market operations.
\end{abstract}

Keywords: financial deepening; economic growth; supply-leading hypothesis; Toda-Yamamoto augmented Granger causality

JEL Classification: $\mathrm{O} 16 ; \mathrm{O} 43$

\section{Introduction}

The concern over rapid economic development has been the focus of Nigeria's development strategies over the past five decades. This is evident in the objectives of its National Development Plans of 1962-1968, 1970-1974, 1975-1980, and 1981-1985, and subsequently the Structural Adjustment Program (SAP) of 1986 and the National Economic Empowerment and Development Strategy (NEEDS) of 2003-2007.

Prior to 1986, the system was under "financial repression" with an undesirable real interest rate, a high tax burden on financial earnings, high liquidity, possible financial misallocations, and reserve requirement ratios (Central Bank of Nigeria, 2003 [1]). After 1986, the financial markets became an active part of the economy. The lifting of repressive controls on financial market instruments was realized gradually over 1986 and beyond as part of policy change. It was expected that the 1986 shift in policy stances in the form of SAP would be a watershed in the life of the national economy. Against all expectations, the Nigerian economy has remained underdeveloped.

Economic theory suggests that the financial sector of any economy is an engine of growth. The argument is that as the financial sector extends credit to the productive sectors of the economy at affordable costs, the overall economy grows inclusively. Unfortunately, the facts of the Nigerian economy point to the contrary. Evidence from the World Bank reveals that in the financial sector's activities, banks' credit to the private sector (\% of GDP) in Nigeria was 12.59 in 2013. Its highest (lowest) values over the past 48 years was 38.35 (3.86), recorded in 2007 (1970). Compare that to South Africa, where banks' credit to the private sector (\% of GDP) was 67.38 in 2013 with the highest (lowest) value for the past 48 years of 78.29 (42.76) recorded in 2007 (1980). In the context of the stock market, 
the turnover ratio for Nigeria declined from $12.53 \%$ in 2010 to $9.21 \%$ in 2011 and further down to $8.79 \%$ in 2012, while that of South Africa increased from 50.74\% in 2010 to $64.26 \%$ in 2011 and declined to 54.93\% in 2012 (World Bank, 2014 [2]).

Furthermore, Figure 1 shows some countries' variation in level of activities of the banking sector, which provides interesting insights about the status of financial inclusion around the world. The wide disparity is noteworthy when comparing financial inclusion trends. The lack of depth of financial inclusion becomes stark when compared to other countries. In general, Nigeria has among the lowest access to bank credits. In 2013 Nigeria had 26.96 per 1000 adults borrowing from banks. It was 110.91 per 1000 adults for Gabon, 405.15 per 1000 adults for Brazil, and 403.35 per 1000 adults for Malaysia. This means that while only 1 in every 37 adults in Nigeria had access to bank credits in 2013, 1 in every 9 adults in Gabon, and 1 in every 2 adults in Brazil and in Malaysia accessed bank credits. According to Soludo, 2008 [3], financial services are available to about 40 percent of the population and more than 60 percent of the poor do not have access to formal finance and are forced to rely on a narrow range of risky and expensive informal services that constrain their ability to participate fully in the markets to increase their income and contribution to economic growth. The limited access to finances and the inadequate lending to economic agents in Nigeria, especially the real sector that could result in economic growth, have raised questions about the effectiveness of financial institutions in meeting their financial intermediation functions.

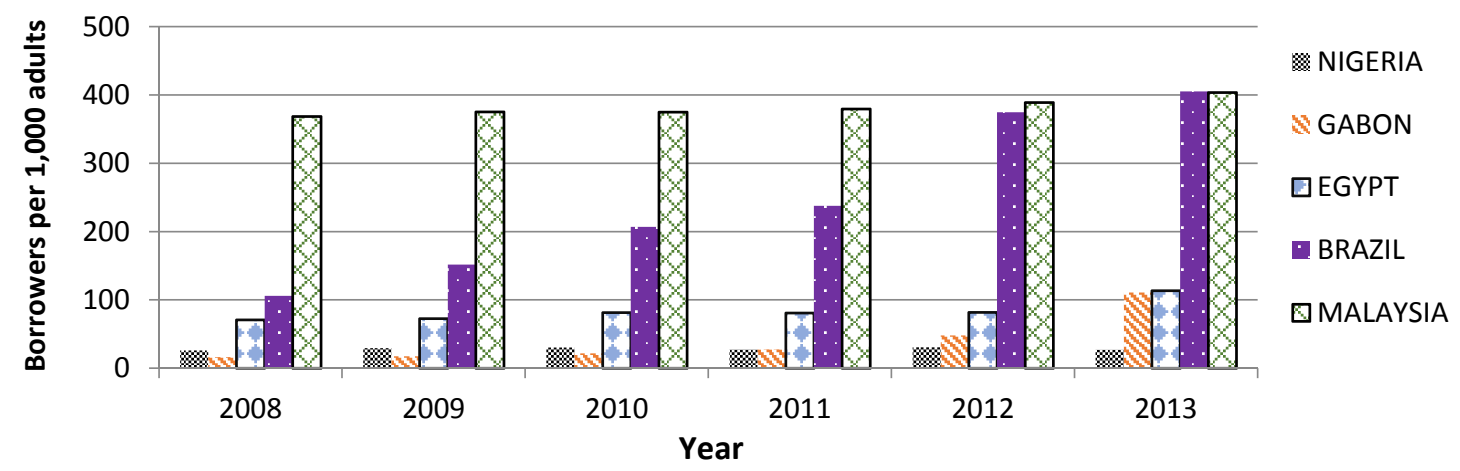

Figure 1. Borrowers from Deposit Money banks per 1000 adults. Source: Authors' computation, with data from the IMF Financial Access Survey, 2014 [4].

However, the empirical debate has been on the direction of causality and the measurement of financial deepening. Four basic hypotheses have been proposed to address the question relating to the direction of causality: (i) does the deepening of the financial system cause economic growth (supply-leading hypothesis); (ii) does growth in economic activity cause a deepening of the financial system (demand-following hypothesis); (iii) is there bi-directional causality between financial deepening and economic growth (feedback hypothesis); and (iv) is there no causal relationship between financial deepening and economic growth (neutral hypothesis)? For over five decades, the direction of causality between financial deepening and economic growth has remained a contentious and unresolved issue (see Akinlo \& Akinlo, 2007 [5]; Agu \& Chukwu, 2008 [6]; Adelakun, 2010 [7]; Odeniran \& Udeaja, 2010 [8]), and studies on the subject matter have produced mixed results across countries and periods.

Furthermore, in an attempt to unravel the controversial debate about the direction of causality between financial deepening and economic growth in Nigeria, various studies have been conducted, with different approaches. In fact, country-specific studies on Nigeria have shown diverse results with two main strands, the supply-leading view and demand-following view. Therefore, there is a need to verify whether the supply-leading hypothesis of the finance-growth nexus is supported in Nigeria by using a different set of financial deepening variables. The recent global financial crisis that translated into economic meltdown of most nations led to bailouts of the financial sector (with 
taxpayers' money) by the governments of the affected countries, including Nigeria. It was believed that once the financial sector was revived, that would translate into reviving the economy and stimulating growth. The bailout of financial institutions in 2009 was also expected to foster an efficient financial system that would encourage greater cooperation and hence engender economic growth. The idea is that bailout should only be considered if causality runs from financial deepening to economic growth, but if the supply-leading hypothesis is not supported a bailout may not impact on the economy. After the bailout in Nigeria, the GDP growth rate immediately rose to $7.8 \%$. It is not clear whether it was the bailout that impacted on growth since growth declined thereafter to $4.8 \%$ in 2011 and further to $4.2 \%$ in 2012 and increased to 5.3\% in 2013 (Central Bank of Nigeria, 2014 [9]). In view of this, there is a need to empirically reinvestigate the direction of causality to better inform policy-making. This study therefore examined the financial development-economic growth nexus in Nigeria with a view to ascertaining whether financial deepening leads or follows growth, that is, if it is the supply-leading hypothesis that holds in Nigeria or the demand-following hypothesis.

\section{Literature Review}

\subsection{Theoretical Framework}

This study is anchored on the supply-leading and demand-following hypotheses of the financial deepening-growth nexus. According to Agu and Chukwu, 2008 [6], the leading proponent of the supply-leading hypothesis is Schumpeter, 1911 [10], supported by Calderon and Liu, 2003 [11], Gurley and Shaw, 1967 [12], King and Levine, 1993 [13], and McKinnon, 1973 [14], among others. The hypothesis asserts that financial development has a positive effect on economic growth. Accordingly, the effect runs from financial development to economic growth and it is caused by an improvement in the efficiency of capital accumulation or an increase in the rate of savings as well as the rate of investment. One of the most significant effects of the supply-leading approach is that, as entrepreneurs have new access to the supply-leading funds, their expectations increase and new horizons (or possible alternatives) are opened up, thereby making the entrepreneur "think big".

The demand-following view, on the other hand, states that financial development responds to changes in the real sector. The Keynesian theory of financial deepening asserts that financial deepening occurs due to an expansion in government expenditure. In order to reach full employment, the government should inject money into the economy by increasing government expenditure. An increase in government expenditure increases aggregate demand and income, thereby raising demand for money (Mckinnon, 1973 [14]). Robinson, 1952 [15] reveals that it is the necessity from high economic growth that creates demand in the financial sector. Thus, in this view, it is the improvements in the economy that drive higher demand for the use of money, which consequently promotes financial development. In other words, financial markets develop and progress as a result of increased demand for their services from the growing real sector. Causality runs from economic growth to financial development, that is, an increase in economic growth causes a rise in demand for financial services and this results in the expansion of the financial sector (Goldsmith, 1969 [16]; Jung, 1986 [17]; Kar \& Pentecost, 2000 [18]; Lucas, 1988 [19]; Ndlovu, 2013 [20]; Omotor, 2007 [21]; Robinson, 1952 [15]).

In between the supply-leading and demand-following hypotheses there are two other views; the first is the feedback hypothesis. This postulates that there is a mutual effect between financial development and economic growth. The second is the neutral hypothesis, which asserts no relationship between financial development and economic growth (Apergis \& Levine, 2007 [22]).

In conclusion, the causal relationship between financial development and economic growth depends on the stage of economic development. In the early stages of economic development, the supply-leading view can stimulate real capital formation. The development of new financial services creates new opportunities for savers and investors and causes an increase in economic growth. The supply-leading view become less important as financial and economic development proceed, and gradually the demand-leading view start to dominate. Patrick states that one industry can be 
encouraged financially on the basis of a supply-leading view, and, when it develops, its financing shifts to demand-leading. Other industries that are still at a low level of development will remain in the supply-leading phase (Patrick, 1966 [23]).

\subsection{Empirical Literature}

With respect to empirical studies in Nigeria, our study is related to a rather limited empirical literature that distinguished the impact of size and level of activity of financial deepening variables on economic growth in Nigeria, although a plethora of empirical works exists on other countries. The empirical literature in Nigeria is mostly on the causality and aggregated impact of financial deepening on economic growth.

Some recent work in Nigeria has extended knowledge about the causal relationships between financial development and economic growth. Some empirical evidence lent support to the idea that financial deepening spurs economic growth, with the authors contending that the creation of financial institutions and their services predates the demand for them. Thus, the availability of financial services stimulates the demand for these services by the entrepreneurs in modern growth sectors. For example, Ibrahim and Shuaibu, 2013 [24] examined the finance-growth nexus for Nigeria using the bounds testing approach to cointegration within an ARDL framework proposed by Pesaran et al. and the augmented Granger causality test developed by Toda and Yamamoto for the period 1970-2010. The variables of interest for the study are ratio of broad money to GDP (MG), which captures financial development, population growth (POP), and gross fixed capital formation (GFCF), which were included as explanatory variables in the empirical specification and growth rate of real gross domestic product (EG) as a measure of economic growth. Empirical evidence reveals that financial development significantly affects economic growth in the short and long run. This result is reinforced by the Toda-Yamamoto causality test, which showed that financial development leads to growth.

In a related study, Adelakun, 2010 [7] empirically examined the relationship between financial development and economic growth using GY, which is the annual growth of gross domestic product (GDP), real interest rate (R), the ratio of gross domestic savings to GDP (S), the ratio of domestic credit to private sector to GDP (P), ratio of liquidity liabilities to GDP (M), the ratio of gross fixed capital formation to GDP (I), and trade openness (T). The perceived relationship between financial development and economic growth was estimated using the Ordinary Least Squares Estimation Method (OLSEM). The results showed that there is a substantial positive effect of financial development on economic growth in Nigeria. The Granger causality test showed that financial development promotes economic growth, but there is evidence of causality from economic growth to the development of financial intermediaries.

In a similar but more extensive study, Sanni, 2012 [25] examines foreign capital inflows, financial deepening, and economic growth in Nigeria for the period 1986-2009. The variables used for the study include real gross domestic product, total capital inflows, and money supply. The Johansen-Juselius cointegration test results suggest that foreign capital inflows, financial deepening, and economic growth are positively cointegrated and that there exists at least one cointegrating vector at the $5 \%$ level of significance, which indicates that there is a long-run relationship between the four variables. The empirical result shows that foreign capital inflows and financial deepening contribute to economic growth in Nigeria; hence, economic policy should focus on issues that will enhance foreign capital inflows and the depth of the financial system.

Attempts have also been made to investigate the supply-leading hypothesis in cross-country studies. An earlier empirical treatment was by King and Levine, 1993 [13], whose body of empirical work established that financial deepening is an intrinsic part of the growth process and may be causal-that is, repressed financial systems are inimical to economic growth.

In his empirical study, as reported by Nzotta, 2004 [26], Goldsmith, 1969 [16] calculated the values of the financial interrelation ratio (FIR), the ratio of all financial instruments at a given time, to the value of the national wealth. He found that the ratios for developing countries were far 
lower than those of developed countries and concluded that because the development of financial institutions affects development, the low level of development of the financial superstructure negatively affects development.

Similarly, Calderon and Liu, 2003 [11] examined the direction of causality between financial development and economic growth by using the Geweke decomposition test on pooled data of 109 developing and industrial countries from 1960 to 1994. The study finds that financial development generally leads to economic growth; the Granger causality from financial development to economic growth and the Granger causality from economic growth to financial development coexist. The study concludes that financial deepening contributes more to causal relationships in developing countries than in industrialized countries.

Ndebbio, 2004 [27] investigated financial deepening, economic growth, and development for Sub-Saharan African countries. The study employed two financial deepening variables, namely the degree of financial intermediation measured by M2 as ratio to GDP, and the growth rate of per capita real money balances. The study revealed that development in the financial sector of these countries spurs sustainable economic growth.

Johannes et al., 2011 [28] using Johansen cointegration established positive relationships between financial development and economic growth in both the long run and short run in Cameroon for the period 1970-2005 at the 5\% level of significance. The results agreed that financial sector development causes economic growth in the long run and the short run, that is, economic growth is a result of financial sector development.

In another line of empirical evidence, Khan, 2008 [29] used the Autoregressive Distributed Lag (ARDL) framework to examine the relationship between financial development and economic growth in Pakistan from 1961 to 2005. His results revealed that in the short and long run, financial development and investment impact positively on economic growth. The results also reveal that in the short run, real deposit rate impacts significantly on real output, while in the long run real deposit rate and economic growth have an insignificant positive relationship.

Furthermore, it is noteworthy that a large amount of historical and econometric evidence suggests that financial development facilitates economic growth; it is important to reiterate that this does not rule out the possibility of a causal relationship in the reverse direction (Sahoo, 2014 [30]). It is perfectly possible that financial systems develop in response to higher economic growth or in anticipation of future prosperity. These two causal processes are not mutually exclusive and may very well be a natural feature of the links between finance and economic growth. Therefore, the issue of direction of causality between finance and growth remains unsettled between the four leading hypotheses, the supply-leading hypothesis, the demand-following hypothesis, the feedback hypothesis, and the neutral hypothesis.

In contrast to the supply-leading hypothesis, empirical findings that support the demand-following view state that growth in economic activity leads to a deepening of the financial system. This means that demand for financial services is determined, for instance, by the growth of real output, commercialization, and modernization of agriculture. This suggests that the expansion of the financial system is led by real economic growth. Empirical findings that support this hypothesis in country-specific evidence include Omotor, 2007 [21], who established that financial development and economic growth exhibit one-way causality. The study used annual data for Nigeria over the period 1970-2002 to construct a multivariate vector auto-regression (VAR) model and Granger causality tests using real GDP, net domestic credit, net investment, trade openness, and human capital investment. The empirical result shows that the direction of causality between financial development and economic growth is demand-following.

The finding of Agu and Chukwu, 2008 [6] is quite different from other authors on Nigeria. They employed the Multivariate Johansen-Juselius framework and Toda-Yamamoto causality tests between "bank-base" financial deepening and economic growth in Nigeria between 1970 and 2005 using per capita income, bank sector's credit to private sector to GDP, the ratio of broad money to GDP, 
the ratio of bank deposit liabilities to GDP, and the loan deposit ratio. The cointegration test results suggest that financial deepening and economic growth are positively cointegrated and that there is only one cointegrating vector indicating a stable and sustainable long-run equilibrium relationship in the Full Information Maximum Likelihood (FIML). In the Toda-Yamamoto sense, their findings revealed evidence to support both demand-following and supply-leading hypotheses, depending on the financial deepening variable that is used.

Similarly, Audu and Okumoko, 2013 [31] studied financial development and economic growth in Nigeria. Their study covered the period between 1970 and 2012. The study estimated the long-run relationship between financial development and economic growth using the Johansen full information maximum likelihood method. Empirical results suggest that all the variables used except ratio of money supply to GDP (MGDP) and the ratio of credit issued to non-financial private firms to total domestic credit (CNFPF) positively influenced financial development and economic growth. The Granger causality results revealed that there is a unidirectional relationship running from lending rate to gross domestic product, financial deepening to GDP. Also, a unidirectional relationship runs from bank credit to the private sector via GDP, MGDP, and the ratio of commercial bank deposit to gross domestic product (RDEP), while a bi-directional relationship exists between LCNFPF and LGDP as well as between RDEP and MGDP.

Odeniran and Udeaja, 2010 [8] studied financial sector development and economic growth in Nigeria. Their study covered the period between 1960 and 2009 and four variables-namely, ratios of broad money stock to GDP, growth in net domestic credit to GDP, growth in private sector credit to GDP, and growth in banks deposit liability to GDP-were used to proxy financial sector development, and real GDP per capita was used to measure real growth rates with 1990 as the base year. They tested the competing finance-growth nexus hypotheses using a Granger causality test in a VAR framework. They found that various measures of financial development cause output in the Granger framework even at the $1 \%$ level of significance, with the exception of ratio of broad money to GDP. They found the existence of a bi-directional relationship between some of the proxies of financial development and economic growth. They also found that net domestic credit is equally driven by growth in output, indicating unidirectional causality.

Osuji and Chigbu, 2012 [32] investigated the impact of financial development variables on economic growth in Nigeria using three variables: gross domestic product (GDP), money supply (M2), and credit to the private sector (CPS). Granger causality testing and the Error Correction Method (ECM) were employed on time series data from 1960 to 2008 and the results revealed that Money Supply (MS) and Credit to Private Sector (CPS) are positively related to economic growth of Nigeria. The Johansen and Granger tests show that Money Supply and Credit to private Sector (CPS) are cointegrated with GDP in Nigeria within the study period and the Granger tests indicated that all the exogenous variables Granger-cause GDP and GDP Granger-causes other variables in Nigeria.

Nzotta and Okereke, 2009 [33] studied financial deepening and economic development in Nigeria using eight indicators: financial deepening (M2/GDP), Financial Savings/GDP ratio (FS/DGP), Private Sector Credit/GDP (PSC/GDP), value of Checks Cleared to GDP ratio (CHQ/GDP), value of Checks Cleared to Money Supply (CHQ/MS2), the Rate of Inflation (INFLA), Prime lending rates (PLRA), and the intermediation ratio. The two-stages least squares analytical framework was used in the analysis. Using data covering the period between 1986 and 2007, the study found that the financial system has not sustained an effective financial intermediation, especially credit allocation and a high level of monetization of the economy.

In another study, Nkoro and Uko, 2013 [34] empirically examined the financial sector development-economic growth nexus in Nigeria. In doing this, the study employed the cointegration/Error Correction Mechanism (ECM) with annual datasets covering the period, 1980-2009. Five variables, namely ratios of broad money stock to GDP, private sector credit to GDP, market capitalization-GDP, banks deposit liability to GDP, and Prime interest rate were used to proxy financial sector development and real gross domestic product growth was used to proxy economic growth. 
The empirical results show that there is a positive effect of financial sector development on economic growth in Nigeria. However, extending credit to the private sector and financial sector depth are ineffective and fail to accelerate growth. This signifies the effect of government borrowing, the problem of huge non-performing loans, and a deficient legal system on the private sector. These severely limit the contribution of Nigeria's financial sector development to economic growth. To sustain and enhance the existing relationship between financial sector development and economic growth in Nigeria, there is a need to adequately deepen the financial system through innovation, adequate and effective regulation and supervision, a sound and efficient legal system, efficient mobilization of funds, and making such funds available for productive investment and improved services.

In another study [35], Olofin and Afangideh's investigation of financial structure and economic growth in Nigeria, they used a three-stage least square estimation technique on data spanning 1970 to 2005 and discovered that a developed financial system reduces growth financing constraints by increasing bank credit and investment activities, with a resultant rise in output. Similarly, Adams, 1998 [36] studied financial intermediation and economic growth in Nigeria. The study employed the 2SLS method to show that the financial intermediation process is sub-optimal and caused by a high lending rate, high inflation rate, low per capita income, and inadequate bank branches. Azege, 2004 [37] examined the empirical relationship between the level of development by financial intermediaries and growth in Nigeria. The study employed data on aggregate deposit money bank credit over time and gross domestic product to establish that a moderately positive relationship exists between financial deepening and economic growth.

Attempts have also been made to gather cross-country evidence that supports the demand-following view. Kar and Pentecost, 2000 [18] examined the causal relationship between financial development and economic growth in Turkey. The study developed five alternative proxies for financial deepening. Granger causality tests were employed using the cointegration and vector error correction methodology developed by Johansen, 1998 [38] and Johansen and Juselius, 1990 [39]. Their results show that the direction of causality between financial development and growth is highly sensitive to the choice of proxy used for financial development. They further found that economic growth seems to lead financial sector development in Turkey.

Ndlovu, 2013 [20] examined financial sector development and economic growth in Zimbabwe for the period 1980-2006. The study used real Gross Domestic Product (GDP) per capita as a measure of economic growth, including Stock Market Capitalization Ratio to GDP, Liquid Liabilities to GDP ratio, and Domestic Credit to Private to GDP; three control variables were used, namely Inflation, Real Interest Rate, and Openness of economy. Using a multivariate Granger causality test, the study found demand-following financial development in Zimbabwe, where there is unidirectional causality from economic growth to financial development. Similarly, Waqabaca, 2004 [40] examined the causal relationship between financial development and growth in Fiji using low-frequency data from 1970 to 2000. The study employed unit root testing and the cointegration technique within a bivariate VAR framework. Empirical results suggest a positive relationship between financial development and economic growth for Fiji, with causality running from economic growth to financial development. He posited that this outcome is common in countries that have less sophisticated financial systems.

Michael, 2012 [41] studied financial development and economic growth and assessed whether Schumpeter was right. Using South Africa as a case study (data ranging from 1965 to 2010) and applying Full Modified Ordinary Least Squares (FMOLS) and Two Stage Least Squares (2SLS), the study found that, contrary to the prediction of Schumpeter, finance promotes growth. The empirical results suggest that financial development does not promote economic growth in either the short run or the long run. The paper concludes that Schumpeter may not be right in theorizing that finance promotes economic growth.

Mohammed and Sidiropoulos, 2006 [42] investigated the effect of financial development on economic performance in Sudan from 1970 to 2004. The study estimated the short-run and long-run relationship between financial development and economic growth and other conditioning variables on 
economic growth using the autoregressive distributed lag (ARDL) model of cointegration analysis proposed by Pesaran and Shin, 1999 [43]. Their results indicated a weak relationship between financial development and economic growth in Sudan due to the inefficient allocation of resources by banks, poor quality of bank credit allocation along with the absence of an appropriate investment climate required to foster significant private investment and promote growth in the long run, and the poor quality of credit disbursal of the banking sector in Sudan.

Frank and Eric, 2012 [44] examined financial sector deepening and economic growth in Ghana. The Johansen co-integration techniques within a bi-variate vector auto-regressive framework were used for the regression. Using a quarterly time series set of data on Ghana over a 10-year period (2000-2009), the result of the study shows that there is a statistically significant positive relationship between the Financial Sector Development and Economic Growth in Ghana.

Thornton, 1994 [45] investigated the role of financial deepening and economic growth in Asian economies. The study used two proxies of financial deepening, namely the ratio of the broad money supply to nominal GDP; and the ratio of total deposits to nominal GDP against real output measured by real GDP in 1985 prices. He employed the cointegration analysis and the Granger causality technique to data for nine Asian economies in an attempt to distinguish between competing hypotheses regarding the role of financial deepening and economic growth. The cointegration analysis does not detect evidence of a long-run or equilibrium relationship between financial deepening and real GDP, while the Granger causality results suggest that in many cases financial deepening does not make much difference to the rate of economy growth in the short run.

\subsection{Limitations of Previous Studies}

There is no doubt whatsoever that a plethora of empirical works exists in the area of financial deepening and economic growth, but most of the studies were based on financial measures that may not capture the mechanism through which financial deepening can cause economic growth. They merely analyzed the causality and/or the impact of financial deepening on economic growth. None of them differentiated between the size of the financial sector and the level of activity in this sector as alternative sources of growth. Further, most of the studies used broad money and credit to the private sector as two different variables in the same econometric model. This may lead to the problem of multicollinearity as credit to the private sector is an intrinsic component of broad money, which may result in type I error.

Therefore, a significant contribution of this study was the recognition that financial services may affect the growth process through multiple channels, some of which depend on the size of the financial institution, while others depend on the level of activity in financial institutions. This allows for an analysis of the quantity and quality of financial institutions in the relationship between financial deepening and economic growth, and for recognizing the problems that multicollinearity poses.

For robust empirical investigation, the Toda-Yamamoto causality framework was used to test the causality direction. This methodological procedure is useful because it allow for tests of augmented Granger causality between financial deepening and economic growth while accounting for the long-run information often ignored in systems that require first differencing and prior to estimation. None of the previous works reviewed in Nigeria considered the superiority of the Toda-Yamamoto causality test except for Agu and Chukwu, 2008 [6] and Ibrahim and Shuaibu, 2013 [24], but they limited their study to bank-based variables and ignored the importance of stock-market-based variables.

\section{Methodology}

\subsection{Data and Sources}

The study adopted annual time series data spanning the period 1970-2013. Although there are a diversity of institutions that operate in the financial sector with many indicators for different financial institution, this study used bank-based and market-based size and level of activity measures 
as financial deepening variables. All the data were obtained from various editions of the Central Bank of Nigeria Statistical Bulletin, the National Bureau of Statistic (NBS) Statistical Fact Book, the Security and Exchange Commission (SEC) Annual Abstracts, and the World Bank Metadata database.

\subsection{Model Specification}

This study adopted the Augmented Granger Causality Test developed by Toda and Yamamoto, 1995 [46]. The financial deepening and economic growth model is presented in the following VAR system:

$$
\begin{aligned}
& G R_{t}=\alpha_{0}+\sum_{j=1}^{k+d \max } \alpha_{1 j} G R_{t-j}+\sum_{j=1}^{k+d \max } \alpha_{2 j} B R_{t-j}+\sum_{j=1}^{k+d \max } \alpha_{3 j} C R_{t-j}+\sum_{j=1}^{k+d \max } \alpha_{4 j} M R_{t-j}+ \\
& \sum_{j=1}^{k+d \max } \alpha_{5 j} T R_{t-j}+\sum_{j=1}^{k+d \max } \alpha_{6 j} L R_{t-j}+\varepsilon_{1 t} \\
& B R_{t}=\lambda_{0}+\sum_{j=1}^{k+d \max } \lambda_{1 j} G R_{t-j}+\sum_{j=1}^{k+d \max } \lambda_{2 j} B R_{t-j}+\sum_{j=1}^{k+d \max } \lambda_{3 j} C R_{t-j}+\sum_{j=1}^{k+d \max } \lambda_{4 j} M R_{t-j}+ \\
& \sum_{j=1}^{k+d \max } \lambda_{5 j} T R_{t-j}+\sum_{j=1}^{k+d \max } \lambda_{6 j} L R_{t-j}+\varepsilon_{2 t} \\
& C R_{t}=\varphi_{0}+\sum_{j=1}^{k+d \max } \varphi_{1 j} G R_{t-j}+\sum_{j=1}^{k+d \max } \varphi_{2 j} B R_{t-j}+\sum_{j=1}^{k+d \max } \varphi_{3 j} C R_{t-j}+\sum_{j=1}^{k+d \max } \varphi_{4 j} M R_{t-j}+ \\
& \sum_{j=1}^{k+d \max } \varphi_{5 j} T R_{t-j}+\sum_{j=1}^{k+d \max } \varphi_{6 j} L R_{t-j}+\varepsilon_{3 t} \\
& M R_{t}=\delta_{0}+\sum_{j=1}^{k+d \max } \delta_{1 j} G R_{t-j}+\sum_{j=1}^{k+d \max } \delta_{2 j} B R_{t-j}+\sum_{j=1}^{k+d \max } \delta_{3 j} C R_{t-j}+\sum_{j=1}^{k+d \max } \delta_{4 j} M R_{t-j}+ \\
& \sum_{j=1}^{k+d \max } \delta_{5 j} T R_{t-j}+\sum_{j=1}^{k+d \max } \delta_{6 j} L R_{t-j}+\varepsilon_{4 t} \\
& T R_{t}=\pi_{0}+\sum_{j=1}^{k+d \max } \pi_{1 j} G R_{t-j}+\sum_{j=1}^{k+d \max } \pi_{2 j} B R_{t-j}+\sum_{j=1}^{k+d \max } \pi_{3 j} C R_{t-j}+\sum_{j=1}^{k+d \max } \pi_{4 j} M R_{t-j}+ \\
& \sum_{j=1}^{k+d \max } \pi_{5 j} T R_{t-j}+\sum_{j=1}^{k+d \max } \pi_{6 j} L R_{t-j}+\varepsilon_{5 t} \\
& L R_{t}=\psi_{0}+\sum_{j=1}^{k+d \max } \psi_{1 j} G R_{t-j}+\sum_{j=1}^{k+d \max } \psi_{2 j} B R_{t-j}+\sum_{j=1}^{k+d \max } \psi_{3 j} C R_{t-j}+\sum_{j=1}^{k+d \max } \psi_{4 j} M R_{t-j}+ \\
& \sum_{j=1}^{k+d \max } \psi_{5 j} T R_{t-j}+\sum_{j=1}^{k+d \max } \psi_{6 j} L R_{t-j}+\varepsilon_{6 t}
\end{aligned}
$$

where $G R$ is the annual growth rate of real gross domestic product as a measure of economic growth; $B R$ is bank total asset as a ratio of GDP; $C R$ is ratio of bank credit to private sector to GDP; $M R$ is ratio of market capitalization to GDP; TR is stock market turnover ratio; $L R$ is prime lending rate; $k$ is the lag length, $(k+d \max )$ is the order of VAR; $\alpha_{j}{ }^{\prime} \mathrm{s}, \lambda_{j}{ }^{\prime} \mathrm{s}, \varphi_{j}{ }^{\prime} \mathrm{s}, \delta_{j}{ }^{\prime} \mathrm{s}, \pi_{j}{ }^{\prime} \mathrm{s}$, and $\psi_{j}{ }^{\prime} \mathrm{s}$ are parameters to be estimated; and $\varepsilon_{1 t}, \varepsilon_{2 t}, \varepsilon_{3 t}, \varepsilon_{4 t}, \varepsilon_{5 t}$ and $\varepsilon_{6 t}$ are error terms that are assumed to be white noise.

For the relationship between $B R_{t}$ and $G R_{t}$, equations (1) and (2) are relevant. Causality runs from $B R_{t}$ to $G R_{t}$ if, $\alpha_{2 j} \neq 0$ in equation (1), and from $G R_{t}$ to $B R_{t}$, if $\lambda_{1 j} \neq 0$ in Equation (2). If $\alpha_{2 j} \neq 0$ and $\lambda_{1 j} \neq 0$ do (not) hold simultaneously then, there is feedback (independent) relationship between $B R_{t}$ and $G R_{t}$.

For the relationship between GR and CR equations (1) and (3) are relevant. Unidirectional causality runs from: $C R$ to $G R$ if, at least some $\alpha_{3 j}{ }^{\prime} s \neq 0$ in (1) and all $\varphi_{1 j}{ }^{\prime} s=0$ in (3) and; from GR to $C R$ if, all $\alpha_{3 j}{ }^{\prime} s=0$ in (1) and at least some $\varphi_{1 j}{ }^{\prime} s \neq 0$ in (3). 
The relationship between $G R$ and $M R$ is defined by equations (1) and (4). Unidirectional causality runs: from $M R$ to $G R$ if, at least some $\alpha_{4 j}{ }^{\prime} s \neq 0$ in (1) and all $\delta_{1 j}{ }^{\prime} s=0$ in (4) and; from $G R$ to $M R$ if, at least some $\delta_{1 j}{ }^{\prime} s \neq 0$ in (4) and all $\alpha_{4 j}{ }^{\prime} s=0$ in (1). Feedback relationship exists if $\alpha_{4 j}{ }^{\prime} s \neq 0$ in (1) and $\delta_{1 j}{ }^{\prime} s \neq 0$ in (4) holds simultaneously. The relationship is independent if all $\alpha_{4 j}{ }^{\prime} s=0$ and all $\delta_{1 j}{ }^{\prime} s=0$ simultaneously.

Similarly, unidirectional causality runs: from TR to GR if, at least some $\alpha_{5 j}{ }^{\prime} s \neq 0$ in (1) and all $\pi_{1 j}{ }^{\prime} s=0$ in (5) and; from GR to TR if, at least some $\pi_{1 j}{ }^{\prime} s \neq 0$ in (5) all $\alpha_{5 j}{ }^{\prime} s=0$ in (1). There is feedback if, at least some $\alpha_{5 j}{ }^{\prime} s \neq 0$ in (1) and some $\pi_{1 j}{ }^{\prime} s \neq 0$ in (5) holds simultaneously, and independence exists if, all $\alpha_{5 j}{ }^{\prime} s=0$ in (1) and all $\pi_{1 j}{ }^{\prime} s=0$ in (5).

In the same vein, unidirectional causality runs: from $L R$ to $G R$ if, at least some $\alpha_{6 j}{ }^{\prime} s \neq 0$ in (1) and all $\psi_{1 j}{ }^{\prime} s=0$ in (6) and; from GR to $L R$ if, at least some $\psi_{1 j}{ }^{\prime} s \neq 0$ in (6) and all $\alpha_{6 j}{ }^{\prime} s=0$ in (1). Feedback exists if at least some $\alpha_{6 j}{ }^{\prime} s \neq 0$ in (1) and some $\psi_{1 j}{ }^{\prime} s \neq 0$ in (6). Further, there is independence if, all $\alpha_{6 j}{ }^{\prime} s=0$ in (1) and all $\psi_{1 j}{ }^{\prime} s=0$ in (6).

\subsection{Description of Variables}

Real gross domestic product growth rate $(G R)$ is a proxy for economic growth. This measure provides a high indicative power of the quality and quantity of economic growth.

Total bank assets measure the overall size of the banking sector, which is equal to the total deposit liability of the deposit money bank. The size variable for the banking sector is the value of outstanding assets of the banking sector, which includes bank credit as well as other investments of the banking sector. This determines the capacity of the banking sector to perform its core role of mobilizing savings.

The ratio of bank credit to private sector to GDP is bank-based activity level. Previous studies have revealed that credit to the private sector is the most comprehensive indicator of the activity of financial intermediaries (Levine, Loayza \& Beck, 2000 [47]). This is because it is associated with the system's ability to mobilize resources from the surplus-saving unit and make them available to the deficit-spending unit.

Market capitalization, the value of listed domestic shares on domestic exchanges divided by GDP, shows the overall size of the stock market as a percentage of GDP. The assumption behind this measure is that the overall market size is positively correlated with the ability to mobilize capital and diversify risk on an economy-wide basis (Levine \& Zervos, 1996 [48];).

Stock market turnover ratio measures the level of activity, which is usually given as total value of shares traded divided by market capitalization. Turnover ratio identifies the ease and speed with which economic agents can buy and sell securities. With a high turnover ratio, the initial investors do not lose access to their savings for the duration of the investment project because they can easily, quickly, and cheaply sell their portfolio. Importantly, a large stock market is not necessarily an active liquid market and a large but inactive market will have large capitalization but small turnover. Stock market turnover ratio is the most comprehensive indicator of the activity of stock market and signals whether trading activity is matched by market size.

Prime lending rate is the weighted average lending rate of deposit money banks (percent). It is an indicator of financial access and measures the cost of access and use of financial services. A high level of financial deepening should sustain and provide a basis for a moderate lending rate in the economy.

\subsection{Estimation Technique}

Granger causality was one of the earliest methods developed to quantify the causal effect from time series observations. Causality testing in the Granger sense is conventionally conducted by estimating VAR models: a VAR model in the level data, a VAR model in the first differenced data, and a vector error correction model (Clarke \& Mirza, 2006 [49]). However, it has been observed that VAR estimation often involves nuisance parameters and then no satisfactory basis for supporting a causality test applies as the $F$-test statistic does not have a standard distribution when variables are integrated. Also, the most difficult parts of testing multivariable Granger causality are how to confirm 
the cointegrating relationship and how to estimate the VAR accurately when its system is integrated (Phillip \& Toda, 1994 [50]). However, Engle and Granger,1987 [51], and Johansen and Juselius, 1990 [39] suggest that the inclusion of additional variables such as the error-correction term would help to capture the long-term causal relationship and make causality results meaningful. Yet these tests are still sensitive to the values of trend and constant terms in finite samples and thus not very reliable for typical time series sample sizes (Toda and Yamamoto, 1995 [46]).

Following Rambaldi and Doran, 1996, [52], and Agu and Chukwu, 2008 [6], this study considered the Granger non-causality test, a Toda-Yamamoto procedure that is applicable regardless of whether a series is $\mathrm{I}(0), \mathrm{I}(1)$, or $\mathrm{I}(2)$, non-cointegrated or cointegrated of any order. This implies that it avoids the potential bias associated with unit root and cointegration tests (Rambaldi and Doran, 1996 [52]). As pointed out by Clarke and Mirza, 2006 [49], pre-tests for unit root and cointegration might suffer from size distortions, which often implies the use of an inaccurate model for the non-causality test. To obviate some of these problems, the Toda-Yamamoto test, based on augmented VAR modeling, introduced a Wald test statistic that asymptotically has a chi square $\left(\chi^{2}\right)$ distribution irrespective of the order of integration or cointegration properties of the variables. The Toda-Yamamoto approach fits a standard vector auto-regression and a vector error correction model on levels of the variables (not on their first differences) and therefore makes allowances for the long-run information often ignored in systems that require first differencing and pre-whitening (Clarke \& Mirza, 2006 [49]). The approach employs a modified Wald test (MWALD) for restrictions on the parameters of the VAR $(k)$, where $k$ is the lag length of the system. The basic idea of the Toda-Yamamoto approach is to artificially augment the correct order, $k$, by the maximal order of integration, say $d$ max. Once this is done, a $(k+d \max )$ the order of VAR is estimated and the coefficients of the last lagged $d$ max vectors are ignored (Caporale \& Pittis, 1999 [53]).

\section{Results and Discussion}

The variables for this study were analyzed using descriptive statics and other empirical approaches. The descriptive statistics and correlation matrix emanating from the variables are presented in Tables 1 and 2, respectively. The probability in the descriptive statistic indicated that most of the variables are not normally distributed, showing high values of standard deviation, Jarque-Bera statistics and near zero probabilities. The mean value of bank credit to the private sector as a ratio of GDP (CR) was 13.08, with 6.56, 75.8, and 0.00 standard deviation, Jarque-Bera, and probability values, respectively. Also, the total assets of banking sector as a ratio of GDP $(B A)$ had a mean value of 35.42, with standard deviation of 13.24 and Jarque-Bera statistic of 3.16 and 0.20 probability value. This showed that $B A$ is more normally distributed than $C R$ in terms of deviation in the data series (Table 1).

The annual growth rate of real Gross Domestic Product (GR) had the highest Jarque-Bera statistic of 28.09, with 4.40 and 4.64 mean and standard deviation values, respectively. The prime lending rate $(L R)$, with 1.47 Jarque-Bera statistic, had 14.95 and 16.75 mean and standard deviation values, respectively. The nature of the data series calls for normalization of the variables. First, a correlation test was used to examine the degree of association among the variables. This was necessary to avoid the multicollinearity problem that most of the studies (Agu \& Chukwu, 2008 [6]; Audu \& Okumoko, 2013 [31]; Odeniran \& Udeaja, 2010 [8]; Osuji \& Chigbu, 2012 [32]; Nzotta \& Okereke, 2009 [33]; and Nkoro and Uko, 2013 [34]), which used both broad money and credit to the private sector as different financial deepening indicators, failed to take into consideration. The results are reported in Table 2. All the values of the correlation coefficients were less than 0.8 in absolute terms. In accordance with the econometrics rule of thumb for multicollinearity test, this is an indication of the absence of a multicollinearity problem. 
Table 1. Descriptive statistics.

\begin{tabular}{ccccccc}
\hline Statistic & $\boldsymbol{C R}$ & $\boldsymbol{B A}$ & $\boldsymbol{G R}$ & $\boldsymbol{L R}$ & $\boldsymbol{M R}$ & $\boldsymbol{T R}$ \\
\hline Mean & 13.08425 & 35.42234 & 4.402923 & 14.95818 & 17.33415 & 5.585111 \\
Median & 12.70369 & 32.90723 & 4.649226 & 16.75500 & 10.96388 & 5.403249 \\
Maximum & 38.34855 & 70.67310 & 33.73578 & 29.80000 & 73.75343 & 17.55881 \\
Minimum & 3.862077 & 14.93431 & -13.12788 & 6.000000 & 5.122039 & 0.148551 \\
Std. Dev. & 6.563540 & 13.24457 & 8.080945 & 6.406191 & 14.16887 & 3.500716 \\
Skewness & 1.930973 & 0.653420 & 0.963436 & 0.142541 & 2.376585 & 0.881809 \\
Kurtosis & 8.141648 & 2.867451 & 6.407793 & 2.151042 & 9.170601 & 4.436761 \\
Jarque-Bera & 75.81047 & 3.163231 & 28.09746 & 1.470337 & 111.2264 & 9.486820 \\
Probability & 0.000000 & 0.205643 & 0.000001 & 0.479425 & 0.000000 & 0.008709 \\
Sum & 575.7068 & 1558.583 & 193.7286 & 658.1600 & 762.7026 & 245.7449 \\
Sum Sq. Dev. & 1852.442 & 7543.001 & 2807.972 & 1764.689 & 8632.543 & 526.9655 \\
Observations & 44 & 44 & 44 & 44 & 44 & 44 \\
\hline
\end{tabular}

$C R=$ Ratio of bank credit to private sector to GDP, $B A=$ Bank total asset as a ratio of GDP, GR = Annual growth rate of the real gross domestic product, $L R=$ Prime lending rate, $M R=$ Ratio of market capitalization to GDP, $T R=$ Stock market turnover ratio. Source: Authors' Computation.

Table 2. Correlation matrix.

\begin{tabular}{ccccccc}
\hline & $\boldsymbol{C R}$ & $\boldsymbol{B A}$ & $\boldsymbol{G R}$ & $\boldsymbol{L R}$ & $\boldsymbol{M R}$ & $\boldsymbol{T R}$ \\
\hline $\boldsymbol{C R}$ & 1.000000 & 0.790731 & -0.339515 & -0.435276 & 0.351332 & 0.438212 \\
$\boldsymbol{B A}$ & 0.790731 & 1.000000 & -0.296440 & -0.361842 & 0.346332 & 0.420567 \\
$\boldsymbol{G R}$ & -0.339515 & -0.296440 & 1.000000 & 0.095854 & -0.345424 & 0.013725 \\
$\boldsymbol{L R}$ & -0.435276 & -0.361842 & 0.095854 & 1.000000 & -0.143523 & -0.159583 \\
$\boldsymbol{M R}$ & 0.351332 & 0.346332 & -0.345424 & -0.143523 & 1.000000 & 0.001028 \\
$\boldsymbol{T R}$ & 0.438212 & 0.420567 & 0.013725 & -0.159583 & 0.001028 & 1.000000 \\
\hline
\end{tabular}

Source: Authors' Computation.

Second, the series were examined for unit roots and cointegration. This is a necessary aspect of any policy driven time series analysis, especially as it provides the leeway to avoiding the spurious regression syndrome.

Results for both the Augmented Dickey-Fuller and Philips-Perron unit root tests are presented in Table 3 for levels and first differences of the time series and that of the Johansen's cointegration rank test are presented in Table 4. The results indicate that, though GR, $B A, C R$ and $M R$ were trend stationary, all the variables became stationary after differencing once, that is, they are all integrated of order one I(1).

Table 3. Unit root results.

\begin{tabular}{ccccccc}
\hline \multirow{2}{*}{ Variable } & \multicolumn{3}{c}{ ADF-Statistics } & \multicolumn{3}{c}{ Adj. PP-Statistics } \\
\cline { 2 - 7 } & Level & $\begin{array}{c}\text { 1st } \\
\text { Difference }\end{array}$ & $\begin{array}{c}\text { 1st Difference } \\
\text { Probability }\end{array}$ & Level & $\begin{array}{c}\text { 1st } \\
\text { Difference }\end{array}$ & $\begin{array}{c}\text { Difference } \\
\text { Probability }\end{array}$ \\
\hline$G R$ & $-5.738307^{* *}$ & $-8.695053^{* *}$ & 0.0000 & $-5.746942^{* *}$ & $-13.98251^{* *}$ & 0.0000 \\
$B A$ & $-3.112282^{* *}$ & $-5.727581^{* *}$ & 0.0000 & -2.105332 & $-5.762296^{* *}$ & 0.0000 \\
$C R$ & $-3.152003^{* *}$ & $-5.877677^{* *}$ & 0.0000 & -2.504949 & $-9.433591^{* *}$ & 0.0000 \\
$M R$ & $-4.613153^{* *}$ & $-9.848226^{* *}$ & 0.0000 & $-4.709791^{* *}$ & $-19.43562^{* *}$ & 0.0001 \\
$T R$ & -2.460042 & $-8.538936^{* *}$ & 0.0000 & -2.289743 & $-9.596494^{* *}$ & 0.0000 \\
$L R$ & -1.581782 & $-10.27717^{* *}$ & 0.0000 & -2.034354 & $-10.36160^{* *}$ & 0.0000 \\
\hline
\end{tabular}

Notes: (1) The ADF statistics were generated from a random walk model with drift and trend; (2) The PP test used the Newey-West automatic bandwidth selection technique; (3) ${ }^{* *}$ denotes rejection of the unit root hypothesis at the $5 \%$ level. Source: Authors' computation. 
Table 4. Johansen's co-integration rank test results.

\begin{tabular}{|c|c|c|c|}
\hline \multicolumn{4}{|c|}{ (a) Trace statistic co-integration result } \\
\hline Hypothesized No. of CE(s) & Eigenvalue & Trace Statistic & 5\% Critical Value \\
\hline None* & 0.641836 & 129.1621 & 94.15 \\
\hline At most $1 *$ & 0.582497 & 87.06481 & 68.52 \\
\hline At most $2 *$ & 0.477041 & 51.25285 & 47.21 \\
\hline At most 3 & 0.304575 & 24.67448 & 29.68 \\
\hline At most 4 & 0.174228 & 9.781959 & 15.41 \\
\hline At most 5 & 0.046053 & 1.933035 & 3.76 \\
\hline
\end{tabular}

(b) Maximum eigenvalues co-integration result

\begin{tabular}{cccc}
\hline Hypothesized No. of CE(s) & Eigenvalue & Max-Eigen Statistic & 5\% Critical Value \\
\hline None $^{\dagger}$ & 0.641836 & 42.09731 & 39.37 \\
At most $1{ }^{\dagger}$ & 0.582497 & 35.81197 & 33.46 \\
At most 2 & 0.477041 & 26.57836 & 27.07 \\
At most 3 & 0.304575 & 14.89252 & 20.97 \\
At most 4 & 0.174228 & 7.848924 & 14.07 \\
At most 5 & 0.046053 & 1.933035 & 3.76 \\
\hline
\end{tabular}

* denotes rejection of the null hypothesis at the $5 \%$ level; ${ }^{+}$denotes rejection of the hypothesis at the $5 \%$ level. Source: Authors' computation.

The study also adopted the co-integration method developed by Johansen, popularly called the Johansen co-integration test or cointegration rank test. This test identifies the number of stationary long-run relationships that exist among the set of integrated variables. It offers two tests, the Trace test and the Max-Eigenvalue test. The trace statistic tests the null hypothesis of at least $r$ cointegrating vectors against the alternate of at most $r$. This means that a rejection of the null implies there are at $r$ co-integrating relationships. On the other hand, the Maximum Eigen statistic tests the null hypothesis of at most $r$ cointegrating vectors against the alternate of $r+1$. This means that a rejection of the null implies there are at least $r+1$ co-integrating relationships. Both the Trace and Max-Eigen statistics showed two cointegrating vectors indicating the existence of a long-run relationship among the variables (Table $4 \mathrm{a}, \mathrm{b}$ ). However, because the focus of this study was not to examine the impact of financial deepening on economic growth, there was no need for estimating any error correction model.

As explained earlier, the study adopted the VAR Granger causality/Wald test approach, suggested by Toda and Yamamoto to evaluate the causality relationship between financial deepening and economic growth. The approach compute statistics that asymptotically follow the chi square $\left(\chi^{2}\right)$ distribution irrespective of the order of integration of the variables. In fact, the Toda-Yamamoto approach fits a standard vector auto-regression model on levels of the variables and therefore makes allowance for the long-run information often ignored in systems that require first differencing and pre-whitening (Clarke \& Mirza, 2006 [49]).

Results for the Toda-Yamamoto augmented Granger causality test are reported in Table 5. At a 5\% level of significance, the augmented Granger causality test reveals that all the financial deepening variables in the model jointly have a causal effect on economic growth, but not always individually (as "BA, $C R$ and $M R$ " do not Granger-cause "GR" individually). The results showed that stock market turnover ratio $(T R)$ and prime lending rate $(L R)$ Granger-cause economic growth (GR). Further assessment reveals that the GR equation has a chi square $\left(\chi^{2}\right)$ value of 19.19907 with a probability value of 0.0378 , which suggest rejection of the null hypothesis that financial deepening variables does not Granger-cause economic growth. However, there is no evidence of feedback, which means that economic growth (GR) does not Granger-cause financial development as GR was not significant at the $5 \%$ level in any of the models with financial deepening variables as the dependent variable (see Appendix A). 
Table 5. Toda-Yamamoto augmented Granger causality test.

\begin{tabular}{cccc}
\hline \multicolumn{4}{c}{ Dependent Variable: GR } \\
\hline Excluded & Chi-Square & Degree of Freedom & Probability \\
\hline$B A$ & 2.091518 & 2 & 0.3514 \\
$C R$ & 2.467952 & 2 & 0.2911 \\
LR & 8.359085 & 2 & 0.0153 \\
MR & 3.733386 & 2 & 0.1546 \\
$T R$ & 11.78489 & 2 & 0.0028 \\
All & 19.19907 & 10 & 0.0378 \\
\hline
\end{tabular}

Overall, the causality result supports the view that causality runs from financial development to economic growth, implying that the supply-leading hypothesis prevails in Nigeria. The supply-leading hypothesis was developed by Goldsmith, 1969 [16], who suggested that financial development has a positive causal impact on economic growth as it could boost the capital accumulation efficiency and/or increase the level of savings and thus the level of investment, as suggested by McKinnon, 1973 [14], and Shaw, 1967 [12]. In other words, through a growth in savings and an increase in investment efficiency, financial development may play a key role in growing national output (Levine, 1997 [54]). Moreover, this would create incentives for financial innovations and the implementation of new technology. The Roots of Characteristic Polynomial presented in Figure 2 and Table 6 reveal that no root lies outside the unit circle, indicating that the model satisfies the stability condition and exhibits good fit.

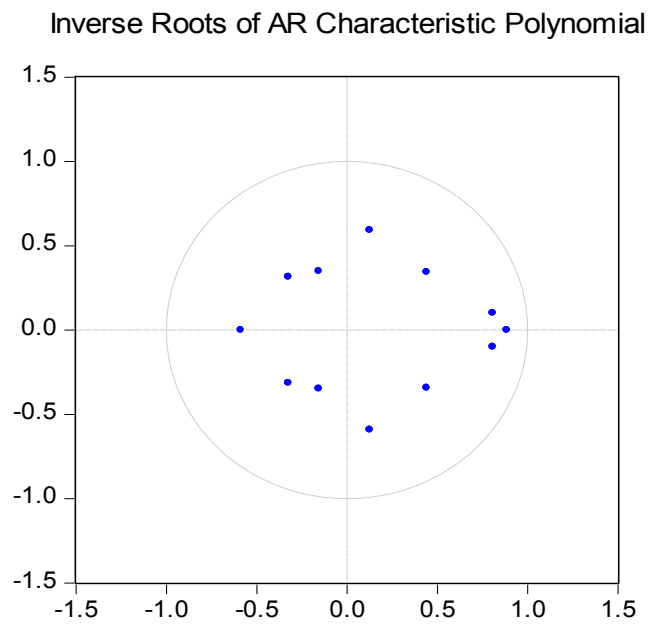

Figure 2. Inverse roots of AR characteristic polynomial result.

Table 6. Inverse roots of AR characteristic polynomial result.

\begin{tabular}{cc}
\hline Root & Modulus \\
\hline 0.884875 & 0.884875 \\
$0.807974-0.099972 \mathrm{i}$ & 0.814135 \\
$0.807974+0.099972 \mathrm{i}$ & 0.814135 \\
$0.126250-0.591362 \mathrm{i}$ & 0.604688 \\
$0.126250+0.591362 \mathrm{i}$ & 0.604688 \\
-0.587398 & 0.587398 \\
$0.442022-0.342579 \mathrm{i}$ & 0.559235 \\
$0.442022+0.342579 \mathrm{i}$ & 0.559235 \\
$-0.323339-0.315568 \mathrm{i}$ & 0.451808 \\
$-0.323339+0.315568 \mathrm{i}$ & 0.451808 \\
$-0.155795-0.348988 \mathrm{i}$ & 0.382184 \\
$-0.155795+0.348988 \mathrm{i}$ & 0.382184 \\
\hline
\end{tabular}




\section{Conclusions and Recommendations}

\subsection{Conclusions}

The conclusion drawn from this study is that the relationship between economic growth and financial deepening in Nigeria follows the "supply-leading hypothesis" and not the "demand-following", "feedback", or "neutral" hypotheses. The policy implication of this finding is that to grow the Nigerian economy attention must be given to the level of development of the financial system as it may boost the capital accumulation efficiency and/or increase the level of savings and thus investment, as suggested by McKinnon, 1973 [14], and Shaw, 1967 [12]. Further, specific attention must be given to the ease of doing business in the stock market and the cost of capital in the money market (financial access). These are fundamental variables that cannot be ignored since it was the stock turnover ratio $(T R)$ and prime lending rate $(L R)$ that individually Granger-caused economic growth $(G R)$.

\subsection{Recommendations}

Effective means of improving credit channels and liquidity to private firms by banks should be encouraged by Central Bank of Nigeria and an aggressive policy should be pursued to remove all obstacles that could undermine the growth of credit to the private sector. Thus, the policy that established Asset Management Corporation should be strengthened in other to free the deposit money banks from a high incidence of non-performing loans, and thereby, enhance their ability to extend more credit to the economy.

The government should encourage monetary authorities like the Central Bank of Nigeria to build a conducive and enabling environment for friendly interest rates so that prospective investors can increase their investment and raise the nation's production capacity. This can be achieved through low unremunerated reserve requirements and adequate physical and financial infrastructure to remove the impediments that lead to a gap between the savings and lending rate. This is because the interest rate is the stimulating factor in savings and investment decisions in the economy.

The capital market is still shallow and there are bottlenecks inhibiting the ease of doing business, hence policy efforts should aim at restoring investors' confidence by improving the institutional and legal framework for stock market operations, and promoting security ownership and efficiency in the stock market. This will also ensure that stock prices truly reflect their actual values or the expected future profitability of companies.

Author Contributions: Oliver Ejike Ogbonna conceived the idea of the paper and designed the outline. Tari Moses Karimo was responsible for Modeling, data sourcing and providing numerical analysis. The authors then split up and wrote the sections equally. Both participated in the revising and editing equally.

Conflicts of Interest: The authors declare no conflict of interest.

\section{Appendix A}

\begin{tabular}{|c|c|c|c|}
\hline \multicolumn{4}{|c|}{ VAR Granger Causality/Block Exogeneity Wald Tests } \\
\hline \multirow{3}{*}{\multicolumn{4}{|c|}{$\begin{array}{l}\text { Date: } 14 \text { October 2015; Time: 13:32 } \\
\text { Sample: } 1970-2013 \\
\text { Included observations: } 42\end{array}$}} \\
\hline & & & \\
\hline & & & \\
\hline \multicolumn{4}{|c|}{ Dependent variable: $B A$} \\
\hline Excluded & Chi-square & Degree of freedom & Probability \\
\hline CR & 0.414173 & 2 & 0.8129 \\
\hline GR & 0.365922 & 2 & 0.8328 \\
\hline LR & 0.236432 & 2 & 0.8885 \\
\hline MR & 0.578120 & 2 & 0.7490 \\
\hline TR & 2.820104 & 2 & 0.2441 \\
\hline All & 5.154918 & 10 & 0.8806 \\
\hline
\end{tabular}




\begin{tabular}{|c|c|c|c|}
\hline \multicolumn{4}{|c|}{ Dependent variable: $C R$} \\
\hline Excluded & Chi-square & Degree of freedom & Probability \\
\hline BA & 0.798868 & 2 & 0.6707 \\
\hline GR & 2.270515 & 2 & 0.3213 \\
\hline LR & 4.072561 & 2 & 0.1305 \\
\hline MR & 3.126561 & 2 & 0.2094 \\
\hline TR & 8.506981 & 2 & 0.0142 \\
\hline All & 17.05607 & 10 & 0.0731 \\
\hline \multicolumn{4}{|c|}{ Dependent variable: $G R$} \\
\hline Excluded & Chi-square & Degree of freedom & Probability \\
\hline BA & 2.091518 & 2 & 0.3514 \\
\hline $\mathrm{CR}$ & 2.467952 & 2 & 0.2911 \\
\hline LR & 8.359085 & 2 & 0.0153 \\
\hline MR & 3.733386 & 2 & 0.1546 \\
\hline TR & 11.78489 & 2 & 0.0028 \\
\hline All & 19.19907 & 10 & 0.0378 \\
\hline \multicolumn{4}{|c|}{ Dependent variable: $L R$} \\
\hline Excluded & Chi-square & Degree of freedom & Probability \\
\hline BA & 2.642556 & 2 & 0.2668 \\
\hline CR & 0.759500 & 2 & 0.6840 \\
\hline GR & 1.256911 & 2 & 0.5334 \\
\hline MR & 0.255097 & 2 & 0.8803 \\
\hline TR & 2.917831 & 2 & 0.2325 \\
\hline All & 11.03855 & 10 & 0.3545 \\
\hline \multicolumn{4}{|c|}{ Dependent variable: $M R$} \\
\hline Excluded & Chi-square & Degree of freedom & Probability \\
\hline BA & 0.594002 & 2 & 0.7430 \\
\hline $\mathrm{CR}$ & 0.123098 & 2 & 0.9403 \\
\hline GR & 0.373803 & 2 & 0.8295 \\
\hline LR & 9.406109 & 2 & 0.0091 \\
\hline TR & 4.127024 & 2 & 0.1270 \\
\hline All & 14.74395 & 10 & 0.1417 \\
\hline \multicolumn{4}{|c|}{ Dependent variable: $T R$} \\
\hline Excluded & Chi-square & Degree of freedom & Probability \\
\hline BA & 3.140361 & 2 & 0.2080 \\
\hline CR & 5.028108 & 2 & 0.0809 \\
\hline GR & 4.495025 & 2 & 0.1057 \\
\hline LR & 3.062545 & 2 & 0.2163 \\
\hline MR & 3.382383 & 2 & 0.1843 \\
\hline All & 11.18014 & 10 & 0.3437 \\
\hline
\end{tabular}

\section{References}

1. Central Bank of Nigeria (CBN). Annual Report and Statement of Account; Central Bank of Nigeria: Abuja, Nigeria, 2003.

2. World DataBank. Explore. Create. Share: Development Data. Available online: http://databank.worldbank. org/data/home.aspx (accessed on 24 July 2015).

3. Soludo, C.C. The Global Financial Meltdown: Briefing of the Senate; The Senate Chambers: Federal Capital Territory, Abuja, 2008; pp. 1-15.

4. International Monetary Fund (2014). IMF Financial Access Survey. Available online: http://fas.imf.org (accessed on 18 April 2016).

5. Akinlo, A.E.; Akinlo, O. Financial development, money, public expenditure and national income in Nigeria. J. Soc. Econ. Dev. 2007, 1, 21-30.

6. Agu, C.C.; Chukwu, J.O. Multivariate causality between financial depth and economic growth in Nigeria. Afr. Rev. Money Financ. Bank. 2008, 7, 7-21. 
7. Adelakun, O.J. Financial sector development and economic growth in Nigeria. Int. J. Econ. Dev. Res. Investig. 2010, 1, 25-41.

8. Odeniran, S.O.; Udeaja, E.A. Financial sector development and economic growth: Empirical evidence from Nigeria. Cent. Bank Niger. Econ. Financ. Rev. 2010, 48, 92-124.

9. Central Bank of Nigeria (CBN). Annual Report and Statement of Account; Central Bank of Nigeria: Abuja, Nigeria, 2014.

10. Schumpeter, J.A. The Theory of Economic Development; Harvard University Press: Cambridge, MA, USA, 1911.

11. Calderon, C.; Liu, L. The direction of causality between financial development and economic growth. J. Dev. Econ. 2003, 72, 371-394. [CrossRef]

12. Gurley, J.; Shaw, E. Financial structure and economic development. Econ. Dev. Cult. Chang. 1967, 15, 333-346. [CrossRef]

13. King, R.G.; Levine, R. Finance and growth: Schumpeter might be right. Q. J. Econ. 1993, 108, $717-737$. [CrossRef]

14. McKinnon, R. Money and Capital in Economic Development; Brookings Institution: Washington, DC, USA, 1973.

15. Robinson, J. The Generalization of the General Theory. In Rate of Interest and Other Essays; Macmillan: London, UK, 1952.

16. Goldsmith, R.W. Financial Structure and Development; Yale University Press: New Haven, CT, USA, 1969.

17. Jung, W.S. Financial development and economic growth: International evidence. Econ. Dev. Cult. Chang. 1986, 34, 333-346. [CrossRef]

18. Kar, M.; Pentecost, E.J. Financial Development and Economic Growth in Turkey: Further Evidence on the Causality Issue; Economic Research Paper No. 00/27; Loughborough University: Loughborough, UK, 2000.

19. Lucas, R.E. On the mechanics of economics development. J. Monet. Econ. 1988, 22, 3-42. [CrossRef]

20. Ndlovu, G. Financial sector development and economic growth: Evidence from Zimbabwe. Int. J. Econ. Financ. Issues 2013, 3, 435-446.

21. Omotor, D. Financial development and economic growth: Empirical evidence from Nigeria. Niger. J. Econ. Soc. Stud. 2007, 49, 209-234.

22. Apergis, H.; Levine, R. Financial development and economic growth: A panel data analysis of emerging countries. Int. Res. J. Financ. Econ. 2007, 8, 225-238.

23. Patrick, H.T. Financial development and economic growth in underdeveloped countries. Econ. Dev. Cult. Chang. 1966, 14, 174-189. [CrossRef]

24. Ibrahim, T.M.; Shuaibu, M.I. Financial development: A fillip or impediment to Nigeria's economic growth. Int. J. Econ. Financ. Issues 2013, 3, 305-318.

25. Sanni, G.K. Foreign capital inflows, financial deepening and economic growth in Nigeria. Niger. J. Econ. Soc. Stud. 2012, 54, 111-135.

26. Nzotta, S.M. Money, Banking and Finance: Theory and Practice; Hudson Jude Publishers: Owerri, Nigeria, 2004.

27. Ndebbio, J.E. Financial Deepening, Economic Growth and Development: Evidence from Selected Sub-Saharan African Countries; African Economic Research Consortium: Nairobi, Kenya, 2004.

28. Johannes, A.T.; Njong, A.M.; Cletus, N. Financial development and economic growth in Cameroon, 1970-2005. J. Econ. Int. Financ. 2011, 3, 367-375.

29. Khan, M.A. Financial development and economic growth in Pakistan evidence based on Autoregressive Distributed Lag (ARDL) Approach. South Asia Econ. J. 2008, 9, 375-391. [CrossRef]

30. Sahoo, S. Financial Intermediation and Growth: Bank-Based versus Market-Based Systems. Margin J. Appl. Econ. Res. 2014, 8, 93-114. [CrossRef]

31. Audu, N.P.; Okumoko, T.P. Financial development and economic growth in Nigeria. Eur. J. Bus. Manag. 2013, 5, 69-81.

32. Osuji, C.C.; Chigbu, E.E. An evaluation of financial development and economic growth of Nigeria: A causality test. Kuwait Chapter Arab. J. Bus. Manag. Rev. 2012, 1, $27-44$.

33. Nzotta, M.S.; Okereke, J.E. Financial deepening and economic development of Nigeria: An empirical investigation. Afr. J. Account. Econ. Financ. Bank. Res. 2009, 5, 52-66.

34. Nkoro, E.; Uko, A.K. Financial sector development-economic growth nexus: Empirical evidence from Nigeria. Am. Int. J. Contemp. Res. 2013, 3, 87-94.

35. Olofin, S.O.; Afangideh, U.J. Financial structure and economic growth in Nigeria: A macro econometric approach. Niger. J. Secur. Financ. 2009, 13, 1-27. 
36. Adams, J.A. Financial intermediation and economic growth: Evidence from Nigeria. J. Econ. Manag. 1998, 5, $27-40$.

37. Azege, M. The Impact of Financial Intermediation on Economic Growth: The Nigerian Perspective; Research Conference Paper for the Lagos State University; Lagos State University: Lagos, Nigeria, 2004.

38. Johansen, S. Statistical analysis of cointegrating vectors. J. Econ. Dyn. Control 1988, 12, 231-254. [CrossRef]

39. Johansen, S.; Juselius, K. Maximum likelihood estimation and inference on cointegration with applications to the demand for money. Bull. Econ. Stat. 1990, 52, 169-210. [CrossRef]

40. Waqabaca, C. Financial Development and Economic Growth in Fiji; Working Papers, No. 03; Economics Department, Reserve Bank of Fiji: Suva, Fiji, 2004.

41. Michael, A. Financial development and economic growth: Is Schumpeter right? Br. J. Econ. Manag. Trade 2012, 2, 265-278.

42. Mohammed, S.E.; Sidiropoulos, M. Finance-Growth Nexus in Sudan: Empirical Assessment Based on an Application of the ARDL Model. In Third International Student Conference Proceeding “Empirical Models in Social Sciences" (p. 47). 2006. Available online: Economics.soc.uoc.gr/macro/11conf/docs/sufian\%205+ final.doc (accessed on 15 April 2016).

43. Pesaran, M.H.; Shin, Y. The Ragner Frisch Contennial Symposium. In An Autoregressive Distributed Lag Modelling Approach to Cointegration Analysis: Econometrics and Economic Theory in 20th Century; Storm, S., Ed.; Cambridge University Press: Cambridge, NY, USA, 1999; pp. 354-391.

44. Frank, G.S.; Eric, M.N. Financial sector deepening and economic growth in Ghana. J. Econ. Sustain. Dev. 2012, 3, 433-448.

45. Thornton, J. Financial deepening and economic growth: Evidence from Asian economies. Sav. Dev. 1994, 18, 41-51.

46. Toda, H.Y;; Yamamoto, T. Statistical inferences in vector autoregressions with possibly integrated processes. J. Econ. 1995, 66, 225-250. [CrossRef]

47. Levine, R.; Loayza, N.; Beck, T. Financial intermediation and growth: Causality and causes. J. Monet. Econ. 2000, 46, 18-41. [CrossRef]

48. Levine, R.; Zervos, S. Stock market development and long-run growth. World Bank Econ. Rev. 1996, 10, 323-339. [CrossRef]

49. Clarke, J.; Mirza, S.A. Comparison of some common methods of detecting Granger non-causality. J. Stat. Comput. Simul. 2006, 76, 207-231. [CrossRef]

50. Phillips, P.C.B.; Toda, H.Y. Vector autoregression and causality: A theorectical overview and simulation study. Econ. Rev. 1994, 13, 259-285.

51. Engle, R.F.; Granger, W.J.C. Co-integration and error correction: Representation, estimation, and testing. Econometrica 1987, 55, 251-276. [CrossRef]

52. Rambaldi, A.N.; Doran, H.E. Testing for Granger Non-Causality in Cointegrated Systems Made Easy; Working Paper in Econometrics and Applied Statistics No. 88; University of New England: Biddeford, ME, USA, 1996.

53. Caporale, G.M.; Pittis, N. Efficient estimation of cointegrating vectors and testing for causality in vector autoregressions. J. Econ. Surv. 1999, 13, 3-35.

54. Levine, R. Financial development and economic growth: Views and agenda. J. Econ. Lit. 1997, 35, 688-726.

(C) 2017 by the authors; licensee MDPI, Basel, Switzerland. This article is an open access article distributed under the terms and conditions of the Creative Commons Attribution (CC BY) license (http://creativecommons.org/licenses/by/4.0/). 